\title{
Weather Factors Affecting 22 Years of Tallgrass Prairie Hay Production and Quality
}

\author{
J. POWELL, S.J. STADLER, AND P.L. CLAYPOOL
}

\section{Abstract}

Tallgrass prairie annual hay production and chemical composition (N, P, K, CA) data from a 23-year study conducted by H.J. Harper, Oklahoma State University, from 1929 through 1951 were correlated with corresponding monthly and seasonal temperature (mean, maximum and minimum, and absolute maximum and minimum), precipitation, wind, spring and fall growing season freeze dates, current and previous year's harvest dates, and previous year's yield. Multiple regression analyses were used to determine the weather variables and multiple regression equations which accounted for the greatest percentage of variation in annual hay production and nutrient concentrations. Equations with 4 independent weather variables for all months prior to the date of hay harvest produced high $R^{2}$ values for production (82\%), and $N$ $(80 \%), P(81 \%), K(81 \%)$ and CA (91\%) concentrations. In general temperature values, especially in the fall of the previous year and January and mid-summer of the current year, accounted for more of the variation in all response variables than did any other kind of weather variable, such as precipitation, wind, or freeze date. Equations with 4 independent weather variables for those months prior to June produced only a moderate $R^{2}$ value $(48 \%)$ for production, but produced high $R^{2}$ values for $N(76 \%), P(74 \%), \mathbf{K}(74 \%)$ and $\mathrm{Ca}$ (79\%) concentrations. Relationships deserving additional research are suggested.

Temporally and spatially, Oklahoma exhibits a unique variety of weather due to the location of the state on the North American continent. Oklahoma's climate is controlled by various air masses (i.e., warm and humid maritime Tropical from the Gulf of Mexico, continental Tropical from the arid southwest, continental Polar from northern Canada, and continental Arctic from the north polar regions) vying for positions over the state.

The weather characteristics of a given area depend upon the frequency and timing of occurrence of these air masses. The frequencies of air mass dominance vary significantly from year to year with the result Oklahomans can usually predict with confidence only that next year's weather will be different from this year's weather. In any given year, the state can experience temperatures and precipitation characteristics of the more humid climate to the east or the more arid characteristics to the west.

Ranchers and other rangeland managers are acutely aware weather conditions cause rangeland forage production to vary widely from year to year. The annual variations in growing conditions make it difficult to predict or interpret vegetational responses to grazing and range improvement practices.

Oklahoma also offers a significant east-west gradient in elevation, precipitation, and soil types and a north-south temperature gradient influencing the relative abundance of subtropical and temperate-origin flora. This makes it difficult to extrapolate research results from one area to another within the state. Consequently, the accuracy of interpretations of Oklahoma's weather-vegetation relationships and dependability of resulting management recommendations are greatly influenced by the length of a data collection period and the particular mix of weather types within that period.

\footnotetext{
Authors are professor of range science, associate professor of geography, and professor of statistics, Oklahoma State University, Stillwater 74078. Jeff Powell is presently professor of range management, Department of Range Management, University of Wyoming, Laramie $\mathbf{8 2 0 7 1}$.

This article is a contribution of the Oklahoma Agricultural Experiment Station as Journal Article No. 4445.

Appreciation is expressed to David Engle and Anne Ewing, Oklahoma State University, for their review and suggestions in preparation of this manuscript.

Manuscript accepted 27 January 1986.
}

Thus, Oklahoma experiences a mix of weather types unlike those which have been studied using similar methods.

We used the variability within Oklahoma's climate to determine the relationships between selected weather factors and tallgrass prairie hay data assembled over 23 years. Harper (1957) collected the database on hay production and nitrogen, phosphorus, potassium and calcium concentrations from 1929 through 1951. This is the longest rangeland time series available in Oklahoma.

\section{Methods}

The original study was conducted on a Norge loam soil (fineloamy, mixed, thermic Vertic Haplustalfs), prairie range site near Stillwater, Okla. $\left(36^{\circ} 09 \mathrm{~N}, 97^{\circ} 05^{\prime} \mathrm{W}\right)$ at an elevation of $300 \mathrm{~m}$ above MSL. Norge loam soils are characteristically over $1 \mathrm{~m}$ deep, with reddish brown or brown loam A horizons 20 to $40 \mathrm{~cm}$ thick, B horizons of reddish brown silty clay loam over yellowish red light clay, and parent material of reddish yellow loam, clay loam, and alkaline old alluvium. The soils are located on gently sloping old terraces often associated with the higher drainage divides of the area (Gray and Galloway 1959). Soil chemical composition in the 0 - to $8-\mathrm{cm}$ surface layer at the test site included $3.9 \% \mathrm{OM}, 0.16 \%$ total $\mathrm{N}, 12.8 \mathrm{meq} / 100 \mathrm{gm}$ total exchangeable bases, $9.3 \mathrm{meq} / 100$ gm exchangeable calcium, and 100 ppm soluble $\mathrm{P}$. The $\mathrm{pH}$ was 6.2 (Harper 1957).

Harper (1957) described the vegetation as an undisturbed prairie, but did not present species composition data. Near Stillwater, good to excellent condition range sites on Norge soils include the dominant grass species: Andropogon gerardii, Sorghastrum nutans, Schizachyrium scoparium, and Panicum virgatum. Although many species of forbs are common on excellent condition, grazed, loamy prairie range sites, mowing at low stubble heights or mowing after mid-July tends to reduce the relative abundance of climax prairie forbs. In Harper's study, mowing dates varied from 10 July to 10 November and averaged 20 August. The stubble height was not described. Because the currently recommended prairie hay harvest date in Oklahoma is about 1 July, the analyses of Harper's data will be more useful for interpreting the effects of weather factors on ungrazed or unmowed prairie plants than for interpreting the effects of weather factors on prairie hay cut at the recommended time of year.

The study was established in 1929 using 10 untreated plots and duplicate plots for each of 10 fertilizer treatments. Fertilization was terminated in 1945 , so for the purpose of comparability over the longest time series possible, analyses for this study were limited to the untreated plots. The loss of yield data in 1948 and lack of chemical analyses of hay cut in 1951 resulted in 22 years of production and chemical composition data. Samples of hay were taken from each plot and analyzed for nitrogen, phosphorus, potassium, and calcium concentrations $(\%)$. Hay yields were obtained by mowing and recorded as air-dry hay.

A number of variables were chosen to represent the weather data at Stillwater during the period 1929 to 1951 . Data were accumulated into plant years which were defined as the period from 1 November of the previous year to the mowing date of the present year. Temperatures were characterized on a monthly basis using the highest temperature recorded in the month (absolute maximum), the lowest temperature recorded in the month (absolute minimum), mean maximum, mean minimum and the mean monthly. The beginning and ending of the growing season were 
Table 1. Weather variables used in multiple regression equations.

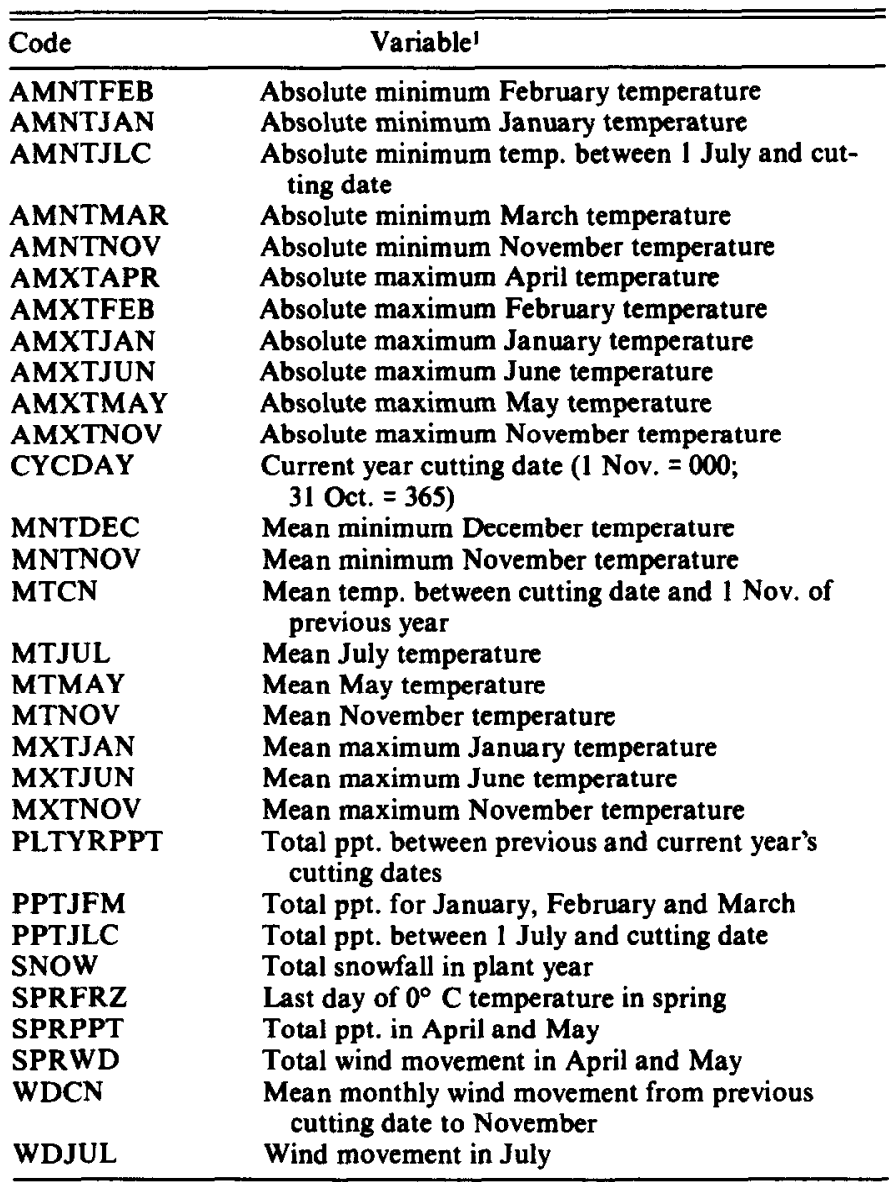

${ }^{1}$ All variable unit magnitude computed from NOAA data. Variables and units are as follows: temperatures (C); precipitation $(\mathrm{mm})$; snowfall $(\mathrm{cm})$; wind movement (km/day). determined through the latest freeze data in the spring and the earliest freeze data in the fall for both 0 and $-2^{\circ} \mathrm{C}$. Monthly precipitation was the cumulative total precipitation for each calendar month. Other variables included total wind movement $(\mathrm{km})$ per month, hay cutting date and winter snowfall total. The total set of variables used in the equations chosen for presentation are shown in Table 1.

Scatter diagrams were used to determine the curvilinearity between response and independent variables. Simple linear correlation coefficients were also determined (Helwig and Council 1979). Stepwise multiple regression was used to determine the combination of independent variables which accounted for the greatest percentage of variation in the various response variables. After multiple equations were derived for each response variable, partial correlation coefficients between the response variable and each independent variable were determined. All regression equations, regression coefficients, and correlation coefficients were significant at the 0.01 level of probabilty unless otherwise specified.

The major objective in developing regression equations was to learn which weather factors acting simultaneoulsy accounted for the greatest variation in each response variable. Cause-and-effect relationships are, at best, only implied. We wanted to generate equations which explained the variation in response variables and pointed out those relationships which appeared to warrant additional research.

Although 22 years is an exceptionally long study period in range research, multiple regression equations using years as observations present realistic limits as to the number of independent variables to be included. The higher the ratio of observations to independent variables, the greater the probablity of the relationships observed being true. Therefore, we arbitrarily limited the number of independent variables in each equation to 4 . This produced a ratio of 5.5 observations per variable in each multiple regression model.

The use of 4 independent variables seemed to be empirically justifiable. As seen in the results presented, equations with 4 independent variables produced high $R^{2}$ values. After examining many equations other than those presented in this paper, it was apparent the addition of the 5th independent variable rarely improved the explanatory power of an equation.

We culled numerous weather variables. Only those used in the

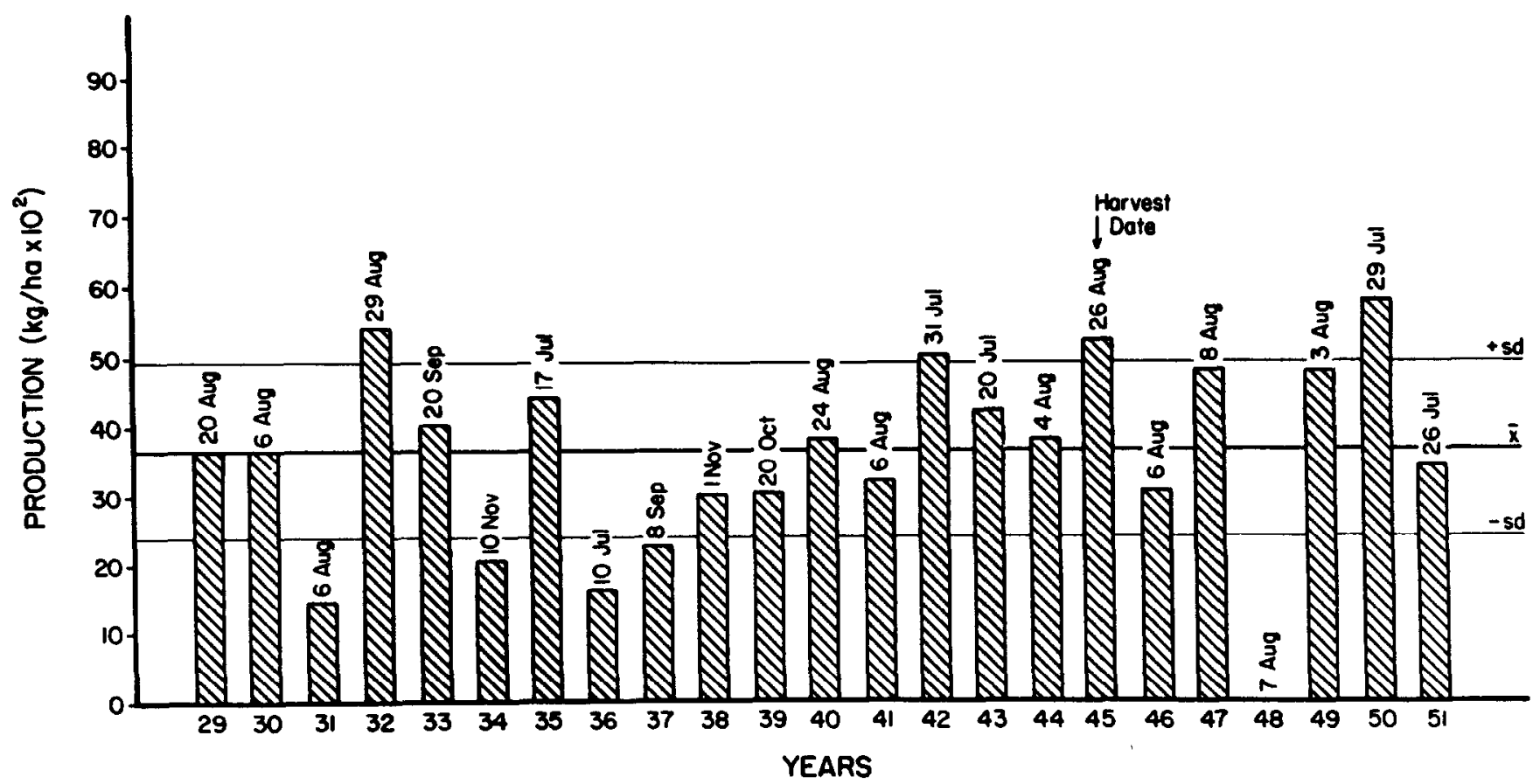

Fig. 1. Annual hay harvest dates and production $\left(\mathrm{kg} / \mathrm{ha}\right.$, air-dry, $\left.\times 10^{2}\right)$ on a tallgrass prairie in North Central Oklahoma. Hay production data were lost for 1948 . 


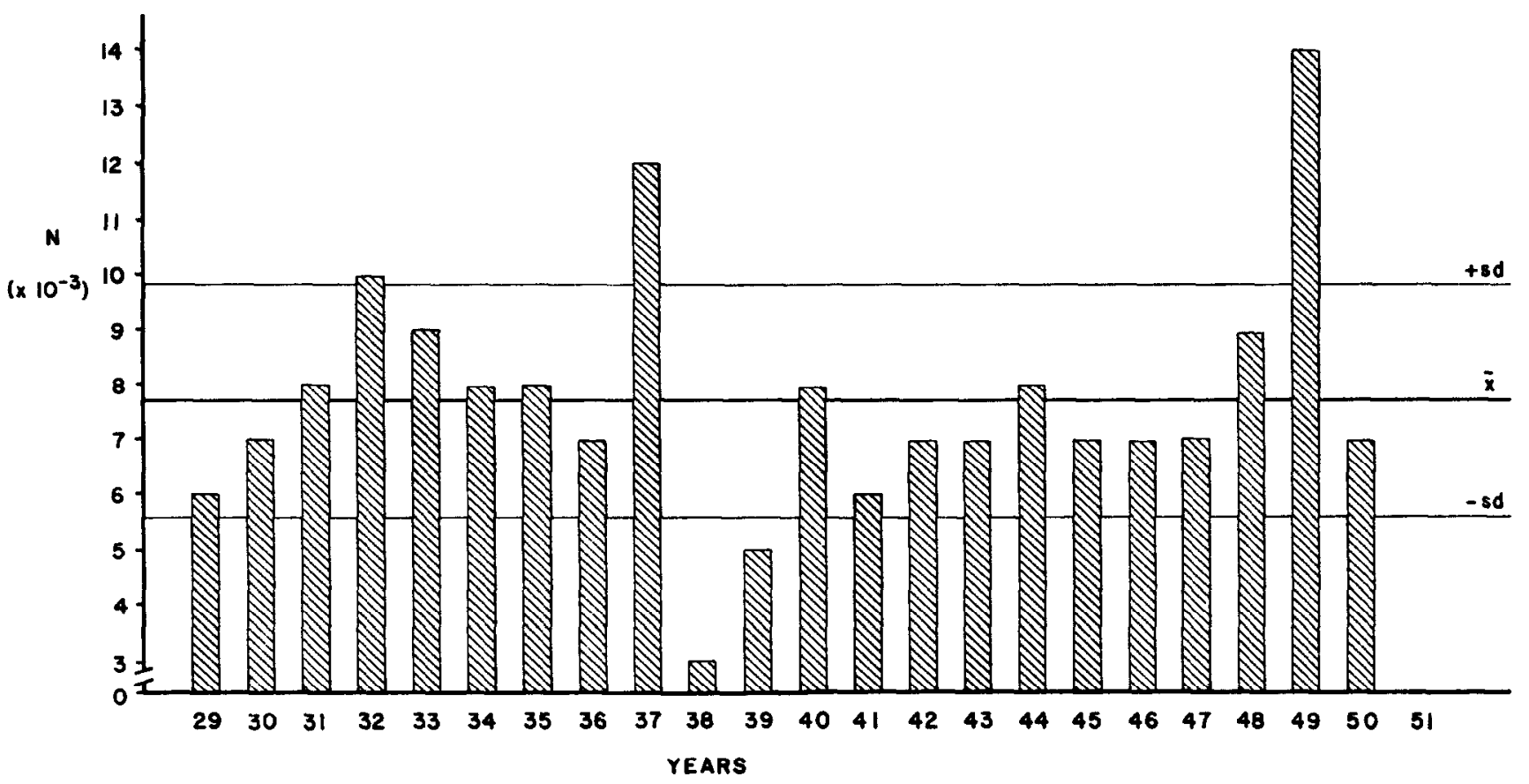

Fig. 2. Annual nitrogen ( $N$ ) concentration (\%) in tallgrass prairie hay in North Central Oklahoma.

final, 4-variable equations are presented. Because so many combinations of variables were possible, we derived the 4-variable equations using a combination of the stepwise regression procedure and a modified, all-possible-regressions procedure.

From all possible 2-variable regressions, we chose the 10 "best" (i.e., maximum variation explained) 2-variable regressions for each response variable. Building onto these, 2-variable combinations, we produced the next "best" set of 3-variable equations. Using these 3-variable equations we added the 4 th independent variable to produce the set of 4-variable equations. From these we selected the 4-variable equation which accounted for the greatest variation in each response variable.

\section{Results and Discussion}

Production and Chemical Composition Annual Variation

Hay production averaged $3,680 \mathrm{~kg} / \mathrm{ha}$ on an air-dry basis with a standard deviation (SD) of $1,260 \mathrm{~kg} / \mathrm{ha}$ (Fig. 1). The least hay yield was $1,300 \mathrm{~kg} / \mathrm{ha}$ in 1931 and the greatest hay yield was $5,800 \mathrm{~kg} / \mathrm{ha}$

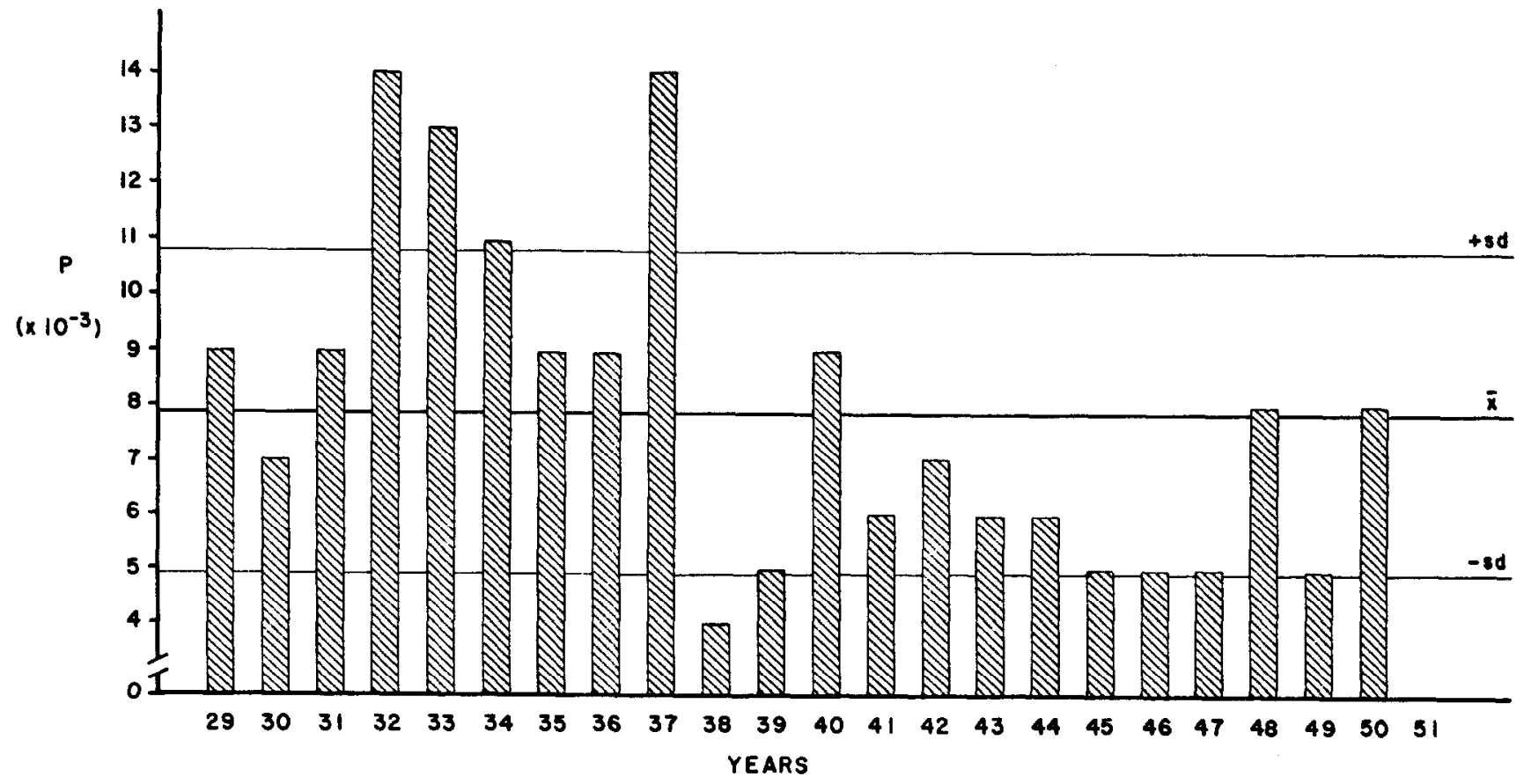

Fig. 3. Annual phosphorus (P) concentration (\%) in tallgrass prairie hay in North Central Oklahoma. 
in 1950. Production was relatively low during the first half of the study period because the severe drought years of the 1930's were included in the first half of the study period.

Nitrogen concentrations varied from $0.33 \%$ in 1938 to $1.36 \%$ in 1949 with an average of $0.78 \%(S D=0.22 \%$ ) (Fig. 2). Other than in 1937-39 and 1949, $\mathrm{N}$ concentrations were relatively uniform throughout the study period.

Phosphorus concentrations were erratic throughout the study period. They varied form $0.04 \%$ in 1938 to $0.14 \%$ in 1932,1933 and 1937 with an average of $0.08 \%(S D=0.035 \%)$ (Fig. 3). During the drier period of 1929-37, P concentrations were generally much higher than during the period of 1938-50.

Potassium concentrations varied from $0.42 \%$ in 1939 to over $1.45 \%$ in $1935-37$ with an average of $1.15 \%(\mathrm{SD}=0.31 \%$ ) (Fig. 4). There were no apparent patterns between $K$ concentrations and the first and second halves of the study period as there were for $P$ concentrations.

Calcium concentrations varied from $0.19 \%$ in 1938 to $0.61 \%$ in 1931 with an average of $0.41 \%(S D=0.10 \%)($ Fig. 5). The year-toyear variation in $\mathrm{Ca}$ concentrations was much greater during the drier period of 1929-39 than during the period of 1940-50.

In general, N, P, K, and Ca concentrations were lowest in 1938 when hay was cut on 1 November. Although chemical concentrations normally decline with delayed cutting, other weather or management factors may obscure the chronological date-ofcutting effect. The concentrations of chemical constituents from the hay cut on 10 November 1934 were greater than those from hay cut on 1 November 1938. Date-of-cutting was more highly correlated with $\mathrm{K}$ (i.e., a mobile nutrient) concentrations $\left(r^{2}=-0.69\right)$ than with $\mathrm{N}\left(r^{2}=-0.19\right), \mathrm{P}\left(r^{2}=-0.13\right)$ or $\mathrm{Ca}\left(r^{2}=-025\right)$ concentrations.

\section{Prediction Models - Prior to Harvest Date Production}

Hay production was most highly correlated $\left(r^{2}=-0.73\right)$ with mean maximum July temperatures (Table 2 ). Mean maximum July temperature accounted for $50 \%$ of the variation in hay production. Other summer temperature variables, such as absolute maximum and mean monthly temperatures, were also negatively correlated with hay yields. July, with mean daily maximum temperatures of $34^{\circ} \mathrm{C}$ and extremes of up to $45^{\circ} \mathrm{C}$, is the hottest month in Stillwater. It is logical to assume plant growth was significantly limited in years with much hotter than average July temperatures (e.g., 1936).

July precipitation was directly related to hay production $r^{2}=$ +0.44 ). The correlation coefficient between mean maximum July temperature and July precipitation was -0.61 . Weather patterns are controlled by ridge patterns in the upper troposphere, so Stillwater's hottest summers also tended to be dry. All simple correlations between hay production and variables other than summer temperatures were less than $\mathbf{0 . 4 0}$.

The higher correlation coefficient for hay yields and July temperature than for hay yields and any of several combinations of monthly precipitation amounts used in our analyses does not imply that the influence of seasonal or annual precipitation on tallgrass prairie production is insignificant. Of the independent variables used to predict hay production under the conditions of Harper's study, July temperature was simply more closely related mathematically to annual hay production than was precipitation.

In a 3-year study near Stillwater, soil water content in a tallgrass prairie decreased rapidly and consistently each year from a maximum in May to a minimum in early August regardless of the amount of precipitation during any season (Powell et al. 1983). The

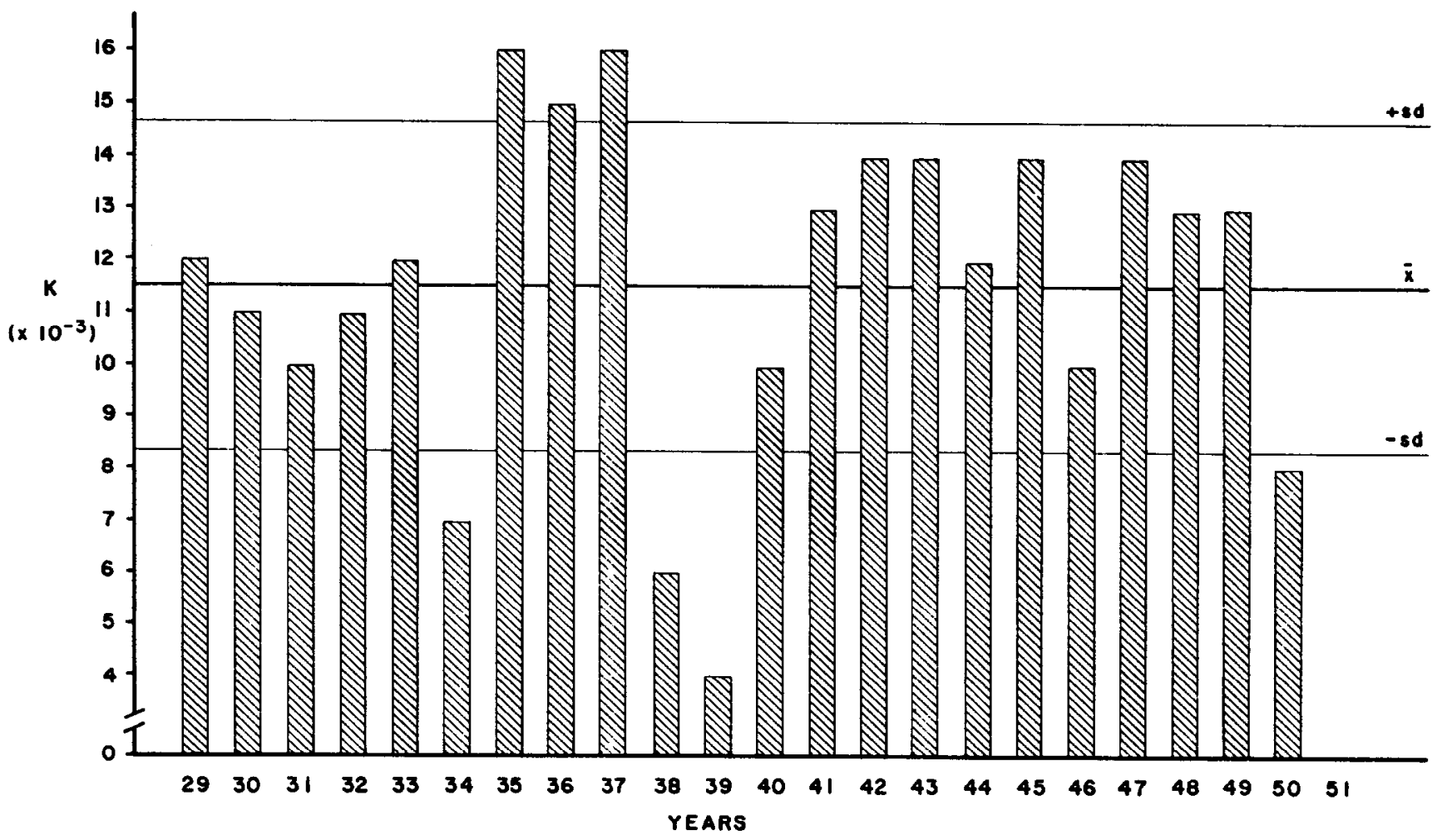

Fig. 4. Annual potassium (K) concentration (\%) in tallgrass prairie hay in North Central Oklahoma. 


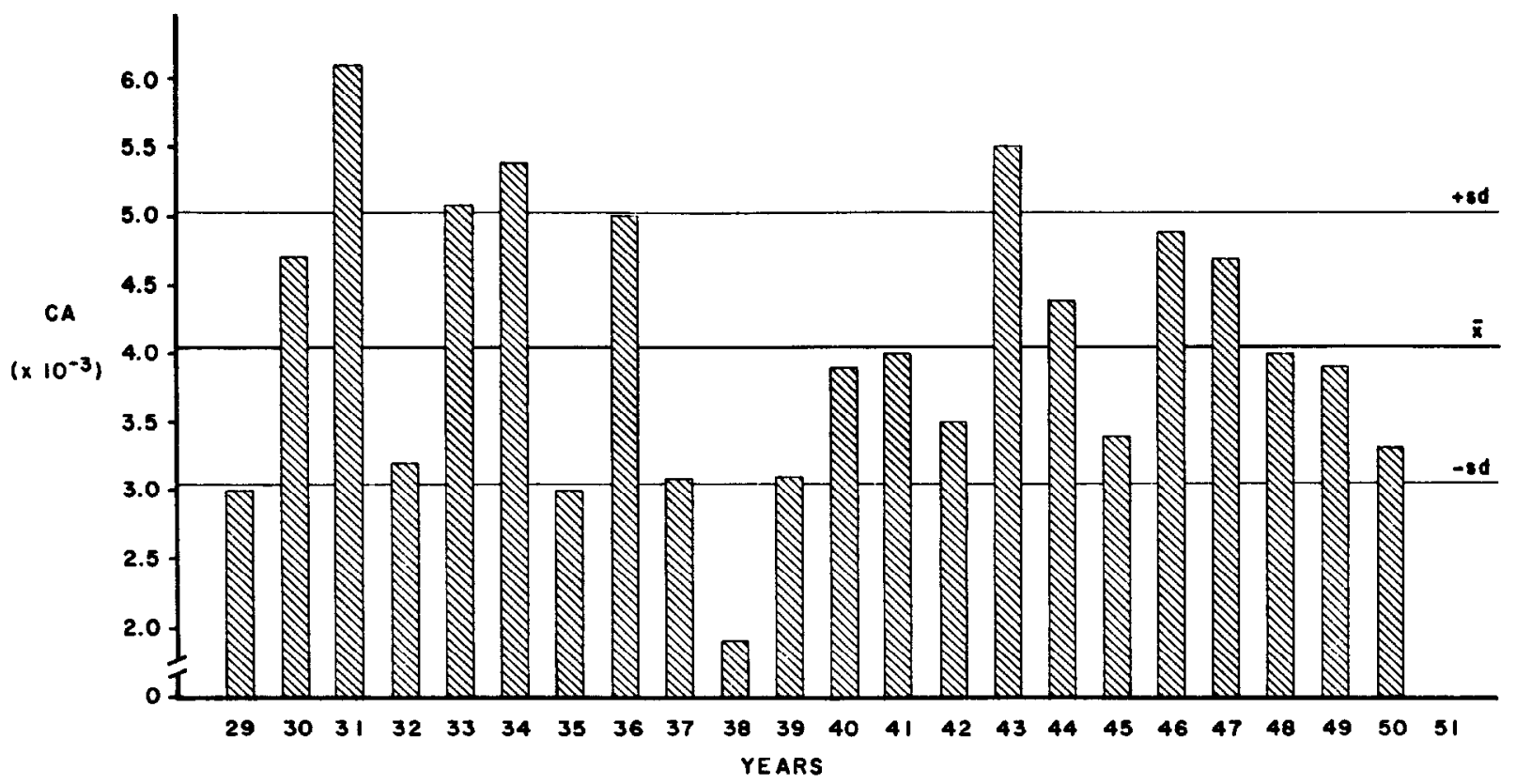

Fig. 5. Annual calcium (CA) concentration (\%) in tallgrass prairie hay in North Central Oklahoma.

amount and date of peak vegetation production varied each year and coincided with the onset of hot, dry weather. A detrimental effect of high air temperatures on soil water use efficiency by tallgrass prairie plants was implied.

Although the literature concerning the effect of additional water on native plant production reports highly variable results (Perry 1976), Shiflet and Dietz (1974) found relatively strong positive correlations between seasonal precipitation and excellent condition tallgrass prairie production in October on southeastern Kansas loamy upland range sites similar to the site used in Harper's study. Shiflet and Dietz (1974) used data collected from several areas over an 8-year period to produce 25 data sets, whereas we used data from a single site and a 22 -year period to produce 22 data sets.
The 4-variable equation suggests hay production decreased with higher mean July and higher absolute minimum March temperatures and increased with higher minimum November and higher spring wind speeds (Table 2). Although precipitation affects production, the effect of high summer temperature on transpiration and soil water use may produce an overriding effect to prematurely decrease the net assimilation rate. The importance of minimum November temperature in this equation deserves additional consideration because of the possible effect of late fall conditions on development of roots and basal buds as the the foundation for the following year's growth.

The relative variation accounted for by different variables as new variables were added was consistent and reflects the low level of collinearity between the independent variables. Partial correla-

Table 2. Regression equations and weather variables (data to date of cutting in current year).

\begin{tabular}{|c|c|c|c|c|c|c|c|c|c|c|}
\hline$b_{0}$ & $b_{1}$ & $\mathrm{X}_{1}$ & $\mathbf{b}_{2}$ & $\overline{X_{2}}$ & $b_{s}$ & $\overline{X_{3}}$ & $b_{4}$ & $X_{4}$ & $R^{2}$ & $\mathrm{SE}_{\overline{\mathbf{y}}}$ \\
\hline $\begin{array}{l}\text { HAY PRODU } \\
+11250 \\
\text { Partial SS } \\
r_{y \cdot x^{4}}\end{array}$ & $\begin{array}{c}\text { (kg/ha): } \\
-571\end{array}$ & $\begin{array}{l}\text { MTJUL }{ }^{1} \\
154 \times 10^{5} \\
-0.73\end{array}$ & +283 & $\begin{array}{l}\text { MNTNOV } \\
54 \times 10^{5} \\
+0.40\end{array}$ & +214 & $\begin{array}{l}\text { SPRWD } \\
39 \times 10^{5} \\
+0.30\end{array}$ & -85 & $\begin{array}{l}\text { AMNTMAR } \\
20 \times 10^{5} \\
-0.25\end{array}$ & $82^{2}$ & 146 \\
\hline $\begin{array}{l}\text { NITROGEN C } \\
-1.24 \\
\text { Partial SS } \\
r_{y . x}\end{array}$ & $\begin{array}{l}\text { JTRATI } \\
+0.066\end{array}$ & $\begin{array}{l}\text { ON (\%): } \\
\text { MTNOV } \\
377 \times 10^{-7} \\
+0.51\end{array}$ & +0.057 & $\begin{array}{l}\text { WDJUL } \\
127 \times 10^{-7} \\
+0.44\end{array}$ & -0.00045 & $\begin{array}{l}\text { PLTYRPPT } \\
127 \times 10^{-7} \\
-0.26\end{array}$ & +0.044 & $\begin{array}{l}\text { MTCN } \\
239 \times 10^{-7} \\
+0.44\end{array}$ & 80 & 0.026 \\
\hline $\begin{array}{l}\text { PHOSPHORL } \\
-0.061 \\
\text { Partial SS } \\
r_{y x}\end{array}$ & $\begin{array}{c}\text { CENTR } \\
+0.102\end{array}$ & $\begin{array}{l}\text { ATION (\%): } \\
\text { WDJUL } \\
52 \times 10^{-8} \\
+0.66\end{array}$ & +0.0032 & $\begin{array}{l}\text { AMNTJLC } \\
55 \times 10^{-8} \\
+0.18\end{array}$ & +0.00018 & $\begin{array}{l}\text { PPTJLC } \\
45 \times 10^{-10} \\
+0.37\end{array}$ & -0.0031 & $\begin{array}{l}\text { AMXTNOV } \\
12 \times 10^{-8} \\
-0.19\end{array}$ & 81 & 0.0035 \\
\hline $\begin{array}{l}\text { POTASSIUM } \\
-0.63 \\
\text { Partial SS } \\
r_{r x}\end{array}$ & $\begin{array}{l}\text { NTRAT } \\
+0.029\end{array}$ & $\begin{array}{l}\text { ION (\%): } \\
\text { AMNTLC } \\
46 \times 10^{-6} \\
+0.77\end{array}$ & +0.061 & $\begin{array}{l}\text { SPRWD } \\
31 \times 10^{-6} \\
+0.17\end{array}$ & -0.001 & $\begin{array}{l}\text { PPTJLC } \\
15 \times 10^{-8} \\
-0.65\end{array}$ & -0.022 & $\begin{array}{l}\text { AMXTJAN } \\
11 \times 10^{-6} \\
-0.12\end{array}$ & 81 & 0.036 \\
\hline $\begin{array}{l}\text { CALCIUM CC } \\
+0.32 \\
\text { Partial SS } \\
\mathbf{r}_{\mathbf{y . x}}\end{array}$ & $\begin{array}{l}\text { TRATIO } \\
-0.02\end{array}$ & $\begin{array}{l}\text { N (\%): } \\
\text { SPRWD } \\
31 \times 10^{-7} \\
-0.68\end{array}$ & +0.076 & $\begin{array}{l}\text { MXTJUN } \\
47 \times 10^{-7} \\
+0.67\end{array}$ & -0.00015 & $\begin{array}{l}\text { CYCDAY } \\
37 \times 10^{-7} \\
-0.25\end{array}$ & -0.033 & $\begin{array}{l}\text { AMXTJUN } \\
13 \times 10^{-7} \\
+0.56\end{array}$ & 91 & 0.009 \\
\hline
\end{tabular}

'See Table 1 for explanation of variable names

4 Simple linear correlation coefficent 
Table 3. Regression equations and weather variables (data prior to 1 June of current year).

\begin{tabular}{|c|c|c|c|c|c|c|c|c|c|c|}
\hline$b_{0}$ & $b_{1}$ & $\mathbf{X}_{1}$ & $\mathrm{~b}_{2}$ & $\mathbf{X}_{2}$ & $\mathbf{b}_{3}$ & $\mathbf{X}_{3}$ & $b_{4}$ & $X_{4}$ & $R^{2}$ & $S E_{\bar{y}}$ \\
\hline $\begin{array}{l}\text { HAY PRODL } \\
+5590 \\
\text { Partial SS } \\
r_{y} x^{4}\end{array}$ & $\begin{array}{l}\text { TION (kg } \\
+428\end{array}$ & $\begin{array}{l}\text { MNTNOV } 1 \\
76 \times 10^{5} \\
+0.40\end{array}$ & -98 & $\begin{array}{l}\text { AMNTJAN } \\
65 \times 10^{5} \\
-0.37\end{array}$ & $\begin{array}{l}-175 \\
P<0.07\end{array}$ & $\begin{array}{l}\text { AMNTNOV } \\
39 \times 10^{5} \\
-0.01\end{array}$ & $\begin{array}{l}-189 \\
P<0.12\end{array}$ & $\begin{array}{l}\text { AMXTAPR } \\
27 \times 10^{5} \\
-0.22\end{array}$ & $48^{2}$ & 246 \\
\hline $\begin{array}{l}\text { NITROGEN } \\
-0.39 \\
\text { Partial SS } \\
r_{\mathbf{y} . \mathbf{x}}\end{array}$ & $\begin{array}{l}\text { ONCENTR } \\
+0.059\end{array}$ & $\begin{array}{l}\text { ITION (\%): } \\
\text { MXTNOV } \\
44 \times 10^{-6} \\
+0.53\end{array}$ & +0.058 & $\begin{array}{l}\text { MTMAY } \\
17 \times 10^{-8} \\
+0.44\end{array}$ & -0.021 & $\begin{array}{l}\text { MXTJAN } \\
12 \times 10^{-8} \\
-0.50\end{array}$ & -0.03 & $\begin{array}{l}\text { AMXTNOV } \\
8 \times 10^{-6} \\
+0.01\end{array}$ & 76 & 0.029 \\
\hline $\begin{array}{c}\text { PHOSPHOR } \\
0.26 \\
\text { Partial SS } \\
r_{y . x}\end{array}$ & $\begin{array}{r}\text { S CONCEI } \\
-0.00026\end{array}$ & $\begin{array}{l}\text { TRATION (\%): } \\
\text { SPRPPT } \\
96 \times 10^{-8} \\
-0.48\end{array}$ & +0.0091 & $\begin{array}{l}\text { MNTDEC } \\
54 \times 18^{-8} \\
+0.34\end{array}$ & -0.00014 & $\begin{array}{l}\text { SPRFRZ } \\
43 \times 10^{-8} \\
-0.04\end{array}$ & +0.00079 & $\begin{array}{l}\text { WDCN } \\
16 \times 10^{-8} \\
+0.34\end{array}$ & 74 & 0.004 \\
\hline $\begin{array}{l}\text { POTASSIUM } \\
+0.061 \\
\text { Partial SS } \\
r_{\text {r.x }}\end{array}$ & $\begin{array}{l}\text { CONCENT } \\
-0.145\end{array}$ & $\begin{array}{l}\text { ATION (\%): } \\
\text { AMXTMAY } \\
111 \times 10^{-6} \\
-0.48\end{array}$ & -0.0044 & $\begin{array}{l}\text { PPTJFM } \\
102 \times 10^{-6} \\
-0.22\end{array}$ & +0.032 & $\begin{array}{l}\text { MXTNOV } \\
17 \times 10^{-6} \\
+0.07\end{array}$ & -0.00086 & $\begin{array}{l}\text { SPRPPT } \\
12 \times 10^{-6} \\
+0.16\end{array}$ & 74 & 0.043 \\
\hline $\begin{array}{l}\text { CALCIUM C } \\
+1.39 \\
\text { Partial SS } \\
r_{y x} .\end{array}$ & $\begin{array}{c}\text { NCENTR } \\
-0.495\end{array}$ & $\begin{array}{l}\text { TION (\%): } \\
\text { SPRWD } \\
15 \times 10^{-7} \\
-0.68\end{array}$ & +0.022 & $\begin{array}{l}\text { AMXTFEB } \\
50 \times 10^{-7} \\
+0.21\end{array}$ & -0.01 & $\begin{array}{l}\text { AMNTFEB } \\
27 \times 10^{-7} \\
+0.17\end{array}$ & -0.00015 & $\begin{array}{l}\text { SNOW } \\
15 \times 10^{-7} \\
-0.23\end{array}$ & 79 & 0.013 \\
\hline
\end{tabular}

ISee Table 1 for explanation of variables names

$2 R^{2}=, P<0.05 ; R^{2}>70, P<0.01$

3Type IV SS, General Linear Models, SAS79

4 Simple linear correlation coefficient

tion coefficients between any 2 of the 4 independent variables in the 4-variable equations were less than 0.06 except for a value of -0.25 between spring wind and absolute minimum March temperature.

\section{Nitrogen}

Nitrogen concentration was most highly correlated $\left(r^{2}=+0.51\right)$ with mean November temperature (Table 2), which accounted for $26 \%$ of the variation in $\mathrm{N}$ concentration. Adding mean May temperature as the 2 nd variable increased the $R^{2}$ value to $51 \%$. Adding plant year precipitation as the 3rd variable increased the $\boldsymbol{R}^{2}$ value to $70 \%$. When mean temperature from the previous cutting date to November was added as the 4th variable, mean May temperature was replaced by July wind movement and the $\boldsymbol{R}^{2}$ value increased to $80 \%$. Collinearity between the independent variables was low and each accounted for a significant portion of the total variation in $\mathbf{N}$ concentrations.

The 4-variable equation used to explain $\mathrm{N}$ concentrations (Table 2) suggests increased precipitation has a negative effect on $\mathbf{N}$ concentration, whereas greater July wind movement and higher temperatures during the period of late summer and fall bud formation increases $\mathbf{N}$ concentration. Possibly, $\mathbf{N}$ concentration is related more to the number of tillers and root absorption than to the larger leaf and stem size usually associated with precipitation.

\section{Phosphorus}

July wind movement was directly related to $P$ concentration and accounted for $44 \%$ of the variation (Table 2). Adding absolute minimum July-to-cutting-date temperature increased the $R^{2}$ value to $55 \%$. Adding current year July-to-cutting-date precipitation as the 3rd variable increased the $R^{2}$ value to $75 \%$. Adding absolute maximum November temperature of the previous year as the 4 th variable increased the $R^{2}$ value to $81 \%$.

$P$ concentrations were greater during years with greater amounts of late summer wind, temperature, and precipitation. These late season variables accounted for $75 \%$ of the variation in $P$ concentration

\section{Potassium}

Absolute minimum July-to-cutting-date temperature was directly related to $\mathrm{K}$ concentrations and accounted for $59 \%$ of the total variation (Table 2 ). Adding spring wind movement as the 2 nd variable increased the $R^{2}$ value to $70 \%$. Adding the 3 rd independent variable, July-to-cutting-date precipitation, increased the $\boldsymbol{R}^{\mathbf{2}}$ value to $76 \%$. The addition of absolute maximum January temperature as the 4 th variable increased the $R^{2}$ value to $81 \%$.

The direct relationship between July temperature and $K$ concentration was similar to that for July temperature and $\mathbf{P}$ concentration although $K$ and $P$ concentrations were not highly correlated $\left(r^{2}+0.18\right)$. July-to-cutting-date precipitation was directly related to $P$ concentration but inversely related to $K$ concentration. Potassium is highly mobile and easily leached. Phosphorus is less mobile and may be increased by greater summer precipitation and temperature.

\section{Calcium}

Spring wind movement was inversely related to Ca concentration and accounted for $\mathbf{4 7 \%}$ of the total variation (Table 2). Mean maximum June temperature greatly increased the $\boldsymbol{R}^{2}$ value to $74 \%$ in the 2-variable equation and accounted for about the same amount of variation as did spring wind movement. Adding current year cutting date as the 3 rd variable increased the $R^{2}$ value to $84 \%$. When absolute maximum June temperature was added as the 4th variable, the $R^{2}$ value increased to $92 \%$, the importance of the current year cutting date variable increased, and the importance of mean maximum June temperature decreased because of collinearity.

The 4-variable equation for $\mathrm{Ca}$ concentrations suggests high spring wind movement and late cutting dates (or some unidentified factors associated with these variables) decreased $\mathrm{Ca}$ concentration. Although higher mean maximum June temperatures appear to increase $\mathrm{Ca}$, the negative regression coefficient for absolute maximum June temperatures suggests there may be an upper limit to the positive effect of higher June temperatures on Ca concentrations. The partial correlation coefficient between mean and absolute maximum June temperatures was +0.90 ; however, the regression coefficients in the equation for both of these variables were highly significant. Accounting for over $90 \%$ of the total variation in $\mathrm{Ca}$ concentration was unexpected because $\mathrm{Ca}$ concentrations are usually unpredictable and highly variable in forage chemical analyses. 


\section{Prediction Models-Prior to 1 June}

The equations in Table 2 included summer weather variables up to the cutting date for each year. Those variables are of little value in predicting hay production and quality early in the growing season when management decisions need to be made. Consequently, we attempted to formulate multiple regression models for the same response variables using only weather data obtainable by 1 June.

\section{Production}

Only $48 \%$ of the variation in hay production could be predicted by 1 June (Table 3). The most important variables in descending order of importance were mean minimum November temperature, absolute minimum January temperature, absolute minimum November temperature, and absolute maximum April temperature. Regression coefficients for the first 2 independent variables were significant at less than 0.05 level, whereas significance levels for the last 2 variables were 0.07 and 0.12 , respectively. The negative regression coefficient for absolute minimum November temperature in combination with the positive regression coefficient for mean minimum November temperature suggests an upper limit to any favorable effect of higher November temperatures on hay yields the following year.

\section{Nitrogen}

About $76 \%$ of the variation in $\mathrm{N}$ concentration could be predicted using weather variable prior to 1 June (Table 3 ). The 4 most important variables, in descending order of amount of variation explained, were mean maximum November temperature, mean May temperature, mean maximum March temperature, and absolute maximum November temperature. All regression coefficients were significant at the 0.01 level. Collinearity was minimal among the independent variables except between mean maximum and absolute maximum November temperatures. The negative regression coefficent for absolute maximum November temperature in combination with the positive regression coefficient for maximum November temperature suggests an upper limit to any favorable effect of higher November temperatures on $\mathrm{N}$ concentrations in hay the following year.

\section{Phosphorus}

About $74 \%$ of the variation in $P$ concentration could be predicted using 4 weather variables prior to 1 June (Table 3 ). These variables were spring precipitation, mean minimum December temperature, date of last $0^{\circ} \mathrm{C}$ temperature in the spring, and mean monthly wind from previous cutting date to November. Although the wind parameter accounted for only a small portion of the total variation in $P$ concentration, its addition to the equation was significant at the 0.05 level.

\section{Potassium}

About $74 \%$ of the variation in $\mathrm{K}$ concentration was explained using 4 weather variables prior to 1 June (Table 3), although $61 \%$ of the total variation was explained with only 2 variables. In the 4-variable equation, absolute maximum May temperature and January-March precipitation accounted for $46 \%$ and $42 \%$ of the regression SS, respectively, and the combination of mean maximum November temperature and spring precipitation explained the remaining $12 \%$ of the regression SS. Collinearity was minimal among this set of independent variables.

\section{Calcium}

Spring wind movement was the variable most highly correlated with CA concentration, accounting for $50 \%$ of the total variation and $63 \%$ of the regression SS (Table 3). The 3 other independent variables, absolute maximum February temperature, absolute minimum February temperatures, and total winter snowfall, accounted for $29 \%$ of the variation in Ca concentration. Although the simple linear correlation coefficient between $\mathrm{Ca}$ concentration and absolute maximum February temperature was similar in magnitude and sign to that for $\mathrm{Ca}$ concentration and absolute min- imum February temperature, the regression coefficients for these variables were opposite in sign. Absolute maximum and absolute minimum February temperatures were only weakly correlated $\left(r^{2}=\right.$ +0.54 ). The opposite signs for regression coefficients for absolute maximum and absolute minimum temperatures in the same equation suggest factors affecting plant functions or soil fertility in the winter may affect $\mathrm{Ca}$ concentration only above or below a particular temperature range.

\section{Conclusions}

Long-term range research studies have great value and may be the only feasible way of determining the net effects of many highly variable factors, such as weather factors, acting simultaneously on plant growth. Mid-summer maximum temperatures had the most significant influence on the variation in long-term prairie hay production and the concentration of potassium, a mobile nutrient. Except in years of gross deficiency, precipitation was of less importance than might be expected.

This apparent contradiction to accepted theory is partially explained by later research in the Stillwater area which showed a maximum soil water content in early spring, followed by a rapid decrease in soil water content with the onset on rapid tallgrass prairie growth. Regardless of the summer precipitation, significant recharge did not occur until after plant production peaked and transpiration was apparently significantly decreased. If much of the summer precipitation from convectional thunderstorms is lost as runoff or plant and litter interception, factors, such as high temperatures and movement of large amounts of dry wind from the southwest, which increase evapotranspiration could be expected to have a greater net effect on plant growth than did precipitation.

Higher minimum temperature in November of the previous year was directly related to greater hay yields and higher $\mathbf{N}$ concentrations in the following year. The implication of this is range managers should pay close attention to the amount of grazing residue left on the plants and the amount of litter on the ground in the fall. Beneficial effects of fall fertilization to increase basal bud and root development for maximum number of tillers is also implied.

The multiple regression equations using data available prior to 1 June more closely predicted forage quality than forage quantity. This could be the result of the influence of fall conditions on tiller potential and general degree of leafiness. Increased forage production may be largely low quality stem materials. Stem elongation may be more limited by hot, dry summer weather than is leaf enlargement on tallgrass species. Peak production in tallgrass prairie vegetation can occur any time between early June and late fall. Hot droughts hasten maturity and relatively cool, wet summers prolong growth.

Extremes in weather variables, especially temperatures, have significant influence over forage quantity and quality. Weather conditions in Oklahoma are highly variable with extremes in temperature, precipitation, and wind. The statistical analyses suggest means and extremes function quasi-independently. These extremes, though short-lived, seemed to have a greater influence on variations in growing conditions than the "expected" average weather conditions.

Although the models presented in this study are not intended to show cause-and-effect relationships, they do point out relationships which deserve additional study. In addition $R^{2}$ values obtained from this long-term study suggest the possible value of obtaining similar data from ranchers with long-term records on hay production and livestock performance. These data could be used with the methods outlined in this study to gain an insight into the weather, vegetation, and livestock performance relationships on other rangelands.

\section{Literature Cited}

Gray, F., and H.M. Galloway. 1959. Soils of Oklahoma. Okla. Agr. Exp. Sta. Misc. Pub. MP-56. 
Harper, H.J. 1957. Effects of fertilization and climatic conditions on prairie hay. Okla. Agr. Exp. Sta. Bull. B-492.

Helwig, J.T., and K.A. Council. 1979.SAS user's guide, 1979 edition. SAS Institute, Inc., Cary, North Carolina.

Perry, D.A. 1976. The effects of weather modification on northern Great Plains grasslands: a preliminary assessment. J. Range Manage. 29:272-8.
Powell, J., F.R. Crow, and D.G. Wagner. 1983. Rangeland watershed water budget and grazing cattle waste nutrient cycling. USEPA Final Report. EPA-600/2-83-017.

Shiflet, T.N., and H.E. Dietz. 1974. Relationships between precipitation and annual rangeland herbage production in southeastern Kansas. $J$. Range Manage. 27:272-6. 